\title{
Effects of livestock on the feeding ecology of endemic culpeo foxes (Pseudalopex culpaeus smithersi) in central Argentina
}

\author{
Efectos del ganado sobre la ecología trófica del zorro culpeo (Pseudalopex culpaeus \\ smithersi) (Carnivora: Canidae) endémico del centro de Argentina
}

\section{MÓNICA V. PIA ${ }^{1,3}$, MARÍA S. LÓPEZ ${ }^{1} \&$ ANDRÉS J. NOVARO²}

\author{
${ }^{1}$ Facultad de Ciencias Exactas Físicas y Naturales, Universidad Nacional de Córdoba, \\ Avenida Velez Sarsfield 299, (5000) Córdoba, Argentina \\ ${ }^{2}$ Wildlife Conservation Society, Centro de Ecología Aplicada del Neuquén (CEAN), \\ Casilla de Correos 7, Junín de los Andes (8371) Neuquén, Argentina \\ ${ }^{3}$ Dirección actual de MVP: Wildlife Conservation Society, Centro de Ecología Aplicada del Neuquén \\ (CEAN), Casilla de Correos 7, Junín de los Andes (8371) Neuquén, Argentina
}

\begin{abstract}
Livestock can affect the feeding ecology of carnivores either directly, by becoming potential prey, or indirectly, by modifying selection of other prey. Selection of other prey is modified through the negative effects of livestock on food and cover, which reduces density and increases vulnerability of wild prey. Pseudalopex culpaeus smithersi is an endemic subspecies of culpeo fox of central Argentina that is persecuted due to predation on livestock. We studied the direct and indirect effects of livestock on P. c. smithersi's feeding ecology by evaluating its diet, prey availability, and prey selection in two areas with different livestock abundance- a national park and an adjacent sheep and cattle ranch in the Achala grassland plateau. We studied diets from feces and used conversion coefficients to estimate prey numbers and biomass consumed. Culpeos preyed primarily on native rodents (cavies and cricetines) according to both prey numbers and biomass. The differences in culpeo diet, prey availability, and prey selection between sites were strongly associated with effects of livestock. Culpeos consumed more livestock carrion and birds at the ranch, and tucos (Ctenomys sp.) only at the park. Livestock density was high at the ranch and low at the park, cricetine and tuco densities were significantly higher at the park, and European hare (Lepus europaeus) densities were similar between sites. According to prey numbers consumed culpeos did not appear to be selective, but according to biomass they consumed cricetines more and hares less than expected at both sites and sheep more than expected at the park. Livestock may reduce densities and increase vulnerabilities of cricetines and fossorial tucos in Achala by soil trampling that destroys burrows, competition for forage, and reduction of grass cover.
\end{abstract}

Key words: culpeo, livestock effects, prey selection, prey availability Pseudalopex culpaeus smithersi.

\section{RESUMEN}

El ganado puede afectar la ecología trófica de los carnívoros en forma directa, siendo una presa potencial, e indirecta, modificando la selección de otras presas. La selección de otras presas es modificada a través de efectos negativos del ganado sobre el alimento y la cobertura, reduciendo la densidad e incrementando la vulnerabilidad de presas silvestres. Pseudalopex culpaeus smithersi es una subespecie endémica de zorro culpeo del centro de Argentina que es perseguida debido a su depredación sobre ganado. Estudiamos los efectos directos e indirectos del ganado sobre la ecología trófica de P. c. smithersi evaluando su dieta y disponibilidad y selección de presas en dos sitios con diferente abundancia de ganado-un parque nacional y una estancia adyacente de ovinos y vacunos en el pastizal de Pampa de Achala. Estudiamos la dieta a partir de heces y utilizamos coeficientes de conversión para estimar el número y biomasa de presas consumidas. Los culpeos depredaron principalmente sobre roedores nativos (cuises y cricétidos) de acuerdo con el número y la biomasa de presas consumidas. Las diferencias en consumo, disponibilidad y selección de presas entre sitios estuvieron fuertemente asociadas con efectos del ganado. Los culpeos consumieron más carroña de ganado y aves en la estancia y tucos (Ctenomys sp.) únicamente en el parque. La densidad de ganado fue alta en la estancia y baja en el parque, las densidades de cricétidos y tucos fueron significativamente mayores en el parque y las densidades de liebre europea (Lepus europaeus) fueron similares entre sitios. De acuerdo con el número de presas consumidas los culpeos no parecieron ser selectivos, pero de acuerdo con la biomasa consumieron más cricétidos y menos liebres que lo esperado en ambos sitios y más ovejas que lo esperado en el parque. El ganado podría reducir las densidades e incrementar la vulnerabilidad de cricétidos y de los cavícolas tucos en Achala a través del pisoteo del suelo que destruye cuevas, la competencia por forraje y la reducción de la cobertura de pastos.

Palabras clave: culpeo, efectos del ganado, selección de presas, disponibilidad de presas, Pseudalopex culpaeus smithersi. 


\section{INTRODUCTION}

Knowledge of carnivore feeding ecology can help us understand the role of carnivores in ecosystems and reduce wildlife-human conflicts due to carnivore attacks on livestock (Estes 1996). Livestock can have direct and indirect effects on the feeding ecology of carnivores, by becoming potential prey and by indirectly modifying selection of other prey by carnivores. Selection of other prey can be modified by livestock through their effects on vegetation and soil, which include reduction of biomass and density of grasses, reduction of litter cover, and soil disturbance that lead to changes in fire regimes, soil erosion, and plant species composition (Fleischner 1994, Belsky \& Blumenthal 1997). These livestockinduced changes, in turn, can alter the density, habitat use, and vulnerability of wild herbivores and omnivores that may be prey of carnivores by affecting their availability of food and cover (Jones 1981, Hayward et al. 1997, Eccard et al. 2000, Stanley \& Knopf 2002).

One approach toward the study of carnivore feeding ecology has been to compare diets and prey selection between areas with different prey bases (Reynolds \& Aebischer 1991). To assess the interactions between predators, their wild prey, and livestock it is necessary to obtain simultaneous evaluations of carnivore diets and availability of wild prey and livestock in different areas. Nevertheless, very few studies (Meriggi \& Lovari 1996, Sacks \& Neale 2002) have conducted these simultaneous evaluations when livestock is a potential prey of carnivores. Sacks \& Neale (2002) found that coyotes (Canis latrans, Say 1823) did not specialize on sheep, killing sheep in proportion to their availability, and that the consumption of large wild prey (deer) was negatively correlated with sheep predation rate. Sacks \& Neale (2002) concluded that the feeding strategy of coyotes in areas with different sheep densities minimized time spent acquiring food rather than maximizing net energy intake (Schoener 1971).

Culpeo foxes (Pseudalopex culpaeus; Molina 1782) are medium-sized canids that live in western and southern South America and are persecuted throughout their range because they prey on sheep and goats (Novaro 1997). Culpeos are opportunistic predators but can be locally selective for certain prey, consuming mainly small mammals and introduced lagomorphs (Lepus eurapaeus, Pallas 1778; Oryctolagus cuniculus, Linnaeus 1758) (Novaro 1997). Some studies have assessed culpeo prey selection (e.g., Iriarte et al. 1989, Jaksic et al. 1992, Johnson \& Franklin 1994, Meserve et al. 1996, Novaro et al. 2000), but none have analyzed prey availability and selection in areas with different livestock abundance.

Pseudalopex culpaeus smithersi (Thomas 1914) is an endemic subspecies of culpeo restricted to a $500-\mathrm{km}^{2}$ portion of the Sierras Grandes, a mountainous area with extensive livestock grazing in central Argentina (Cabrera 1958). Pseudalopex c. smithersi is smaller than other subspecies, has an intense ferruginous coloration, and may be isolated from other culpeo populations in the Andes Mountains to the west by more than 400 $\mathrm{km}$ of plains in La Rioja and San Juan provinces (Cabrera 1931). Pseudalopex c. smithersi is often hunted because it is believed to prey on livestock, but no ecological studies have been done on this subspecies. In this study we conduct an assessment of the direct and indirect effects of livestock on $P$. c. smithersi's feeding ecology by evaluating its diet, prey availability, and prey selection in two areas with different livestock abundance.

\section{MATERIAL AND METHODS}

\section{Study area}

The study was conducted in Pampa de Achala $\left(31^{\circ} 50^{\prime} \mathrm{S}, 64^{\circ} 52^{\prime} \mathrm{W}\right)$, a plateau $(2,000-2,200 \mathrm{~m}$ of altitude) in the Sierras Grandes of Córdoba Province, Argentina. The vegetation is characterized by a steppe dominated by Stipa sp. and Festuca sp. grasses, with patches of Alchemilla pinnata (Ruiz et Pav) at higher altitude (Luti et al. 1979). Mean monthly temperatures range between $5{ }^{\circ} \mathrm{C}$ in winter and $11{ }^{\circ} \mathrm{C}$ in summer (Cabrera 1976). Mean annual precipitation is $850 \mathrm{~mm}$ and is concentrated mainly between October and April.

The Pampa de Achala plateau has been traditionally used as grazing range for cattle (Bos Taurus, Linnaeus 1758) and sheep (Ovis aries, Linnaeus 1758) (Cabido et al. 1999). Our study was done at a site with low livestock density (see Results) in a 5200-ha portion of Quebrada del Condorito National Park where livestock began to be removed in 1998, and a site with high livestock density in the adjacent 4,500-ha Santo Tomás ranch. Mean distance between the sites was $15 \mathrm{~km}$, and topography and vegetation types were similar between sites. The park site that we studied was also a cattle and sheep ranch until the park was created in 1996, so previous land use was similar at both sites, differing only in their current livestock density and average height of grasses as a result of grazing (Cabido et al. 1999, M.V. Pia \& M.S. López personal observations). Each site was sampled during the dry (May-June) and rainy seasons (November-December) of 2000. 


\section{Collection of feces and diet analysis}

We collected culpeo feces along four to eleven $1.1-\mathrm{km}$-long random transects at each site during both seasons and along mountain ridges at the park $(\mathrm{n}=59$ feces, 25 during dry and 34 during rainy season) and ranch $(\mathrm{n}=57,33$ during dry and 24 during rainy season). Feces were distinguished from those of pumas (Puma concolor, Linnaeus 1771) present in the area by their size and shape and were analysed following Reynolds \& Aebischer (1991). Pampas foxes (Pseudalopex gymnocercus, Fischer 1814) are present at lower elevations in the Sierras Grandes of Córdoba, but do not reach Pampa de Achala (M.V. Pia \& M.S. López personal observations). We identified mammalian prey by comparing skulls and teeth to voucher specimens from the region and by analysing hairs with hair keys (Chehebar \& Martin 1989, Fernández \& Rossi 1998). Consumption of live sheep may have been overestimated in our fecal analysis due to our inability to distinguish sheep carrion from sheep that were preyed upon.

We present our results as percent occurrence, representing the number of times each item was encountered in relation to the total number of items in all feces, because this is the type of result most commonly reported in carnivore diet studies (e.g., Jaksic et al. 1980, Johnson \& Franklin 1994, Novaro et al. 2000). Diet data based on feces, however, can be biased due to differential digestibility of prey of different sizes (Weaver 1993). Therefore, we estimated the percent biomass and number of prey consumed by culpeos using correction factors calculated by Lockie (1959) for Vulpes vulpes (Linnaeus 1758), a canid that is similar in size to P.c. smithersi (mean body masses of $P$. culpaeus and $V$. vulpes ranged between 4-10 and 3-11 kg, respectively, Lariviere \& Pasitschniak-Arts 1996, Novaro 1997). These same correction factors have been used in diet studies of other carnivores including mustelids (Lockie 1961, Martín et al. 1995, Travaini et al. 1998). We analysed differences in prey occurrence between seasons and sites with log-linear analysis (Zar 1996).

We estimated relative densities of culpeos using the number of feces found on the random transects at the park $(\mathrm{n}=10$ transects $)$ and ranch $(\mathrm{n}=19)$ (scat deposition transect method; Knowlton 1984, Gese 2001). Relative densities were compared between areas using a randomization test with program RESAMPLING-STATS (Bruce et al. 1995).

\section{Prey availability}

Based on small-mammal distributions (Polop $1989,1991)$ and on a preliminary survey, we expected that the main potential prey of culpeos would be cricetine rodents, hystricognath rodents (Ctenomys sp., Blainville 1826, or tucos, and Galea musteloides, Meyen 1832, Microcavia australis, Geoffrey \& D'Orbigny 1833, and Cavia aperea, Erxleben 1777, or cavies), European hares (Lepus europaeus, Pallas 1778), and young (less than one-year old) domestic sheep. We considered that cattle, horses, and adult sheep were available to culpeos only as carrion (Novaro et al. 2000). Densities of cattle, horses, and sheep were calculated using total counts provided by landowners. Densities of cricetine rodents were assessed using the mark-recapture technique (Otis et al. 1978) by operating three square grids of 49 ( 7 x 7) Sherman traps (separated by $10 \mathrm{~m}$ ) for four consecutive days during both seasons. The grids were set randomly in the dominant grassy habitat of the park and ranch. Data were analyzed using the program CAPTURE (Rexstad \& Burnham 1991). Hare densities were estimated using line transects (Buckland et al. 1993) conducted from a vehicle at night along $20 \mathrm{~km}$ of secondary roads at each site. Transects were surveyed two to four times each season, and data were analyzed using the program DISTANCE (Laake et al. 1996). Due to the underground activity of tucos we were able to estimate only their relative densities. We did this by counting tuco mounds along random transect for culpeo feces (see above) at each site during both seasons and estimating mound densities using program DISTANCE. We were unable to estimate densities of cavies.

Biomass of cricetines, hares, and young sheep was calculated as the product between prey density and mean body mass. Mean body mass was obtained from captured specimens for cricetines, from the literature for hares (Bonino \& Bustos 1994), and from landowners for sheep. We used prey density and biomass as complementary estimators of prey availability (Jaksic et al. 1992, Novaro et al. 2000). Comparisons of prey densities between sites and seasons were done using the program CONTRAST (Sauer \& Williams 1989).

\section{Prey selection}

We studied culpeo prey selection by comparing frequencies of occurrence to relative densities of prey using a goodness-of-fit G-test (Zar 1996) and by comparing estimated biomass and numbers of prey consumed to biomass and densities of 
prey available (Franklin et al. 1999, Novaro et al. 2000). Statistical comparisons were precluded by lack of an appropriate test for biomass proportions and because some expected frequencies of prey consumed were less than 1 (Zar 1996).

\section{RESULTS}

We identified 255 mammalian and 22 bird prey remains in feces of $P$. c . smithersi. The most frequently encountered prey were cricetines and cavies, followed by birds, carrion, hares, tucos, and sheep (Table 1). There was no significant interaction in the diet composition between site and season $\left(\chi^{2}=11.06\right.$, d.f. $\left.=6, P=0.087\right)$ and no significant difference in diets between seasons $\left(\chi^{2}=3.86\right.$, d.f. $\left.=6, P=0.696\right)$, so all subsequent analyses are presented combining data from both seasons. Diets differed significantly between sites $\left(\chi^{2}=20.03\right.$, d.f. $\left.=6, P=0.003\right)$, primarily because culpeos consumed more carrion and birds at the ranch, and tucos only at the park. Considering the biomass consumed, cavies and cricetines were the main prey at both sites, followed by hare at the ranch and tucos at the park (Table 1). We were not able to estimate the biomass of carrion and birds ingested due to lack of correction factors.

Relative densities of culpeos did not differ significantly between the park (1.00 feces- $\left.\mathrm{km}^{-1}\right)$ and ranch $\left(0.86\right.$ feces $\mathrm{km}^{-1}$, randomized t-test, $\mathrm{P}=$ 0.766). Number of feces found on transects were

\section{TABLE 1}

Percent occurrence $(\% \mathrm{O})$ of prey in culpeo fox feces, percent biomass $(\% \mathrm{~B})$ and number of prey consumed $(\% \mathrm{~N})$ by culpeos in Pampa de Achala (central Argentina). Missing percentages $(-)$ are those that could not be calculated with correction factors

Porcentaje de ocurrencia $(\% \mathrm{O})$ de presas en heces de culpeo, porcentaje de biomasa (\%B) y número de presas consumidas $(\% \mathrm{~N})$ por culpeo en Pampa de Achala (Argentina central). Los porcentajes ausentes (-) son aquellos que no pudieron ser calculados con factores de corrección

\begin{tabular}{|c|c|c|c|c|c|c|}
\hline \multirow[t]{2}{*}{ Prey } & \multicolumn{3}{|c|}{ Ranch } & \multicolumn{3}{|c|}{ Park } \\
\hline & $\% \mathrm{O}$ & $\% \mathrm{~B}$ & $\% \mathrm{~N}$ & $\% \mathrm{O}$ & $\% \mathrm{~B}$ & $\% \mathrm{~N}$ \\
\hline \multicolumn{7}{|l|}{ Mammals } \\
\hline \multicolumn{7}{|l|}{ Order Rodentia } \\
\hline Cricetids (subtotal) & $(40.28)$ & $(26.08)$ & $(80.70)$ & $(39.85)$ & $(20.86)$ & $(75.14)$ \\
\hline Akodon boliviensis & 9.03 & 5.83 & 18.3 & 8.27 & 5.02 & 17.92 \\
\hline Oxymycterus paramensis & 3.47 & 2.21 & 7.02 & 3.76 & 6.77 & 6.36 \\
\hline Phyllotis darwinii & 3.47 & 1.87 & 5.85 & 1.76 & 3.71 & 13.30 \\
\hline Reithrodon auritus & 6.94 & 5.53 & 16.96 & 3.00 & 0.84 & 2.89 \\
\hline Oligoryzomys flavescens & 0.69 & 0.21 & 0.58 & 1.50 & 0.88 & 3.47 \\
\hline Unidentified cricetines & 16.66 & 10.42 & 32.16 & 16.54 & 8.65 & 31.21 \\
\hline Caviidae & 26.39 & 61.82 & 18.71 & 40.60 & 55.47 & 19.65 \\
\hline Ctenomys sp. & 0 & 0 & 0 & 6.01 & 14.07 & 5.20 \\
\hline \multicolumn{7}{|l|}{ Order Lagomorpha } \\
\hline Lepus europaeus & 5.56 & 8.29 & 0.15 & 3.76 & 4.93 & 0.09 \\
\hline \multicolumn{7}{|l|}{ Order Marsupialia } \\
\hline Thylamys pusilla & 0.69 & 0.06 & 0.21 & 0 & 0 & - \\
\hline \multicolumn{7}{|l|}{ Order Artiodactyla } \\
\hline Ovis aries & 2.78 & 3.72 & 0.03 & 1.50 & 4.65 & 0.05 \\
\hline Unidentified & 0.69 & - & - & 0 & - & - \\
\hline Carrion & 9.03 & - & - & 2.26 & - & - \\
\hline Unidentified mammals & 3.47 & - & - & 1.50 & - & - \\
\hline Birds & 11.11 & - & - & 4.51 & - & - \\
\hline Number of prey items & 144 & & & 133 & & \\
\hline Number of feces & 57 & & & 59 & & \\
\hline
\end{tabular}


too small to allow simultaneous testing of culpeodensity differences between sites and seasons, so data from different seasons were grouped.

The combined densities of cattle, horses, and sheep were 1.7 and 29.2 animals $\mathrm{km}^{-2}$ at the park and ranch, respectively. We captured two species of cricetines (Akodon boliviensis, Meyen 1833, and Oxymycterus paramensis, Thomas 1902) at both sites, and their combined density was significantly higher at the park $\left(\chi^{2}=31.08\right.$, d.f. $=$ $3, \mathrm{P}<0.001$, Table 2). Cricetines were 47 and 12 $\%$ of the estimated biomass of prey available at the park and ranch, respectively (Table 3). The relative density of tucos also was significantly higher at the park $\left(61.1 \pm 7.7\right.$ mounds $\left.\mathrm{km}^{-2}\right)$ than at the ranch $\left(1.5 \pm 0.7\right.$ mounds $\mathrm{km}^{-2} ; \chi^{2}=33.32$, d.f. $=3, \mathrm{P}<0.001)$. Hare densities, conversely, were not significantly different between sites $\left(\chi^{2}\right.$ $=2.09$, d.f. $=3, \mathrm{P}=0.553$, Table 2). Densities of cricetines and hares did not differ significantly between seasons $\left(\chi^{2}=2.96\right.$, d.f. $=1, \mathrm{P}=0.086$, and $\chi^{2}=5.92$, d.f. $=3, \mathrm{P}=0.115$, respectively). We could not test for differences in tuco densities between seasons due to the small number of observations during the dry season. The biomass of young sheep was 2 and $15 \%$ of the estimated biomass available to culpeos at the park and ranch, respectively (Table 3 ). There were two lambing seasons each year in the study area, so the density and biomass of young sheep also did not differ markedly between the two study seasons.

Patterns of prey selection were different according to percent occurrences in feces, estimated numbers of prey consumed, or estimated biomasses consumed. According to percent occurrences, culpeos were selective at both sites (ranch: $\mathrm{G}=28.89$, d.f. $=2, \mathrm{P}<0.01$; park: $\mathrm{G}=$ 21.45 , d.f. $=2, \mathrm{P}<0.01$ ), because they preyed on hares more than expected and preyed on cricetines less than expected (Table 2). According to the corrected number of prey consumed, however, culpeos did not appear to be selective at either site because there were no major differences between the expected and estimated number of prey consumed (Table 2). Finally, according to biomass available, culpeos consumed cricetines more than expected (mainly at the ranch), hares less than expected at both sites, and sheep more than expected at the park (Table 3 ).

\section{DISCUSSION}

The differences in Pseudalopex culpaeus smithersi diet, prey availability, and prey selection between sites studied in Pampa de Achala were strongly associated with direct and indirect effects of livestock. Pseudalopex c. smithersi preyed primarily on small and medium-sized native rodents according to both prey numbers and biomass, but opportunistically consumed other prey when these were abundant. Greater consumption of carrion and young sheep at the ranch was likely a direct result of the higher abundance of cattle, horses, and sheep at this site. Conversely, the densities of tucos and cricetines were negatively associated with the abundance of livestock, which indirectly affected the diet and selection of these prey by culpeos. Indirect results of livestock abundance included the consumption

TABLE 2

Prey selection by culpeos based on prey occurrence in feces, percentage of prey consumed, and density of prey in Pampa de Achala. Percentages of prey consumed were calculated applying correction factors from Lockie (1959); expected percentages of prey were calculated from prey densities

Selección de presas por zorros culpeo basado en la ocurrencia de las presas en las heces, porcentaje de presas consumidas, y densidad de presas en Pampa de Achala. Los porcentajes de presas consumidas fueron calculados aplicando factores de corrección de Lockie (1959); los porcentajes esperados de presas fueron calculados a partir de la densidad de presas

\begin{tabular}{|c|c|c|c|c|c|c|c|c|}
\hline \multirow[t]{2}{*}{ Prey } & \multicolumn{4}{|c|}{ Ranch } & \multicolumn{4}{|c|}{ Park } \\
\hline & $\begin{array}{l}\text { Frequency } \\
\text { of } \\
\text { occurrence } \\
\text { in feces }\end{array}$ & $\begin{array}{c}\text { Density } \\
\text { (ind km²) } \\
\pm \mathrm{SD}\end{array}$ & $\begin{array}{l}\text { Estimated } \\
\text { percentage } \\
\text { of prey } \\
\text { consumed }\end{array}$ & $\begin{array}{l}\text { Expected } \\
\text { percentage } \\
\text { of prey } \\
\text { consumed }\end{array}$ & $\begin{array}{l}\text { Frequency } \\
\text { of } \\
\text { occurrence } \\
\text { in feces }\end{array}$ & $\begin{array}{c}\text { Density } \\
\text { (ind km-2) } \\
\pm \mathrm{SD}\end{array}$ & $\begin{array}{l}\text { Estimated } \\
\text { percentage } \\
\text { of prey } \\
\text { consumed }\end{array}$ & $\begin{array}{c}\text { Expected } \\
\text { percentage } \\
\text { of prey } \\
\text { consumed }\end{array}$ \\
\hline Cricetids & 30 & $238 \pm 2.8$ & 99.57 & 94.95 & 28 & $1041 \pm 11.3$ & 99.39 & 98.78 \\
\hline Hares & 8 & $9.5 \pm 4.5$ & 0.28 & 4.06 & 5 & $12.6 \pm 1.9$ & 0.50 & 1.17 \\
\hline Sheep & 4 & $2 \pm 0.2$ & 0.14 & 0.98 & 2 & $0.3 \pm 0.1$ & 0.11 & 0.03 \\
\hline Total & 42 & - & - & - & 35 & - & - & - \\
\hline
\end{tabular}


Prey selection by culpeos based on biomass of prey consumed and biomass of prey available in Pampa de Achala. Biomass of prey consumed was calculated applying correction factors from Lockie (1959); expected biomass of prey was calculated from biomass of prey available

Selección de presas por zorros culpeo basado en la biomasa de presas consumidas y la biomasa de presas disponibles en Pampa de Achala. Las biomasas de presas consumidas fueron calculadas a partir de factores de corrección de Lockie (1959); las biomasas esperadas de las presas fueron calculadas a partir de la biomasa de presas disponibles

\begin{tabular}{|c|c|c|c|c|c|}
\hline \multirow[t]{2}{*}{ Prey } & \multirow{2}{*}{$\begin{array}{c}\text { Body weight } \\
(\mathrm{kg})\end{array}$} & \multicolumn{2}{|c|}{ Ranch } & \multicolumn{2}{|c|}{ Park } \\
\hline & & $\begin{array}{l}\text { Biomass estimated } \\
\text { in the diet }(\%)\end{array}$ & $\begin{array}{l}\text { Biomass expected } \\
\text { in the diet }(\%)\end{array}$ & $\begin{array}{l}\text { Biomass estimated } \\
\text { in the diet }(\%)\end{array}$ & $\begin{array}{l}\text { Biomass expected } \\
\text { in the diet }(\%)\end{array}$ \\
\hline Cricetids & 0.04 & 51.0 & 12.4 & 57.0 & 46.8 \\
\hline Hares & 3.40 & 34.0 & 72.5 & 22.0 & 50.9 \\
\hline Sheep & 6.75 & 15.0 & 15.1 & 21.0 & 2.2 \\
\hline
\end{tabular}

of tucos by culpeos exclusively at the park and the stronger selection (measured as the difference between consumption and availability according to biomass) for cricetines at the ranch.

Livestock may negatively affect densities of cricetines and the fossorial tucos by soil trampling (Weir 1974) that compacts soil and destroys burrows, through competition for forage, reduction of plant cover, and by altering plantspecies composition (Pucheta et al. 1998, Kazmaier et al. 2001). Through a combination of these effects on soil and vegetation, for example, Hayward et al. (1997) found that livestock grazing reduced small mammal density by nearly $50 \%$ at a ciénaga in Arizona. Similarly, livestock grazing at a site in the Chilean matorral drastically reduced the densities of three cricetine species (Simonetti 1983). In Achala, O. paramensis is positively associated with tall and dense grasses (Polop 1989). The combined lower density of $O$. paramensis and A. boliviensis at the ranch during our study, partially due to the capture of only one individual of the first species at the ranch and six at the park, suggests a negative effect of livestock on both cricetines. In addition, livestock-exclosure experiments in Achala (Pucheta et al. 1998, Cabido et al. 1999) have demonstrated that livestock markedly reduces the mean height of grasses and the diversity and abundance of insects, further affecting the vulnerability of and food availability for potential culpeo prey.

Livestock did not appear to affect the density of culpeos nor the availability and selection of European hares in Achala, in spite of its effect on other culpeo prey. The lack of effect on culpeo density may be due to compensation between the negative effects on native prey like cricetines and tucos and the positive effect of increased availability of livestock carrion and young sheep.
Livestock grazing, on the other hand, frequently benefits introduced lagomorphs like hares and rabbits (Oryctolagus cuniculus, Linnaeus 1758) by lowering grass height and reducing shrub cover (Simonetti 1983, Meyers et al. 1994) so the lack of a negative association between livestock and hare densities is not unexpected.

Our results are encouraging in terms of the resilience of at least some components of the mammalian predator-prey assemblage in the Achala grassland (Holling 1986, Pucheta et al. 1998). Livestock removal from the park began only two years before our study, and livestock abundance at the park before removal was as high as it was at the ranch during our study, indicating that the past negative effect of livestock at the park was as strong as at the ranch. Thus, it appears that the effect of livestock on cricetine and tuco abundances and on P. c. smithersi's diet composition in Achala can be reversed relatively quickly. The short duration and comparative approach of our study, however, limit our conclusions on the resilience of this mammalian assemblage to livestock grazing.

The low overall consumption of sheep in Achala, lack of selection for hares, and strong selection for small cricetines suggest that the feeding strategy of culpeos in Achala maximized net energy gain and did not minimize time allocated to food aquisition (Schoener 1971). These results contradict recent findings for coyotes (Sacks \& Neale 2002) and selectivity results for culpeos in another study (Novaro et al. 2000). Culpeo studies in central and northern Chile (e.g., Iriarte et al. 1989, Ebensperger et al. 1991, Jiménez et al. 1996, Meserve et al. 1996) did not obtain availability data for prey other than small mammals, so their selectivity results cannot be compared to ours. Data from Argentine Patagonia 
were based on stomach contents (Novaro et al. 2000), so we assume that they are comparable to our estimated numbers and biomass consumed. Culpeos in Patagonia consumed hares more than expected according to estimated numbers and biomass, whereas in our study hares were consumed in equal proportions or less than expected. The lack of selectivity for hares in $P$. c. smithersi may be due to lower hare densities in Pampa de Achala (9-13 versus 47 hares $\mathrm{km}^{-2}$ in Patagonia), which may be too low to be readily available or profitable (Pyke et al. 1977), and to higher density of cavies in Achala, which weigh 200-600 g (Redford \& Eisenberg 1992) and may be highly profitable for culpeos. Our conclusions on selectivity of prey are limited by the lack of data on availability of cavies, which comprised a large proportion of the biomass of the culpeo diet. Cricetines, on the other hand, were two to ten times more abundant in Patagonia, where they were consumed less than expected. Consumption of cricetines in proportions that are equal to or greater than their availability in Achala, in spite of their low density, may be a consequence of the low availability of the larger (and more profitable) hares. Sheep were consumed by culpeos in Achala less frequently than in Patagonia, but as in the latter region, they were consumed more than expected (at least at the park, where sheep density was low). Selection for sheep in Achala, as in Patagonia, may be due to the absence of large wild prey, which has been extirpated in Achala (Diaz et al.1994) and greatly reduced in abundance in Patagonia (Novaro et al. 2000).

Our selectivity analysis illustrates the difficulties of interpreting diet data from feces. Conclusions obtained considering the percent occurrence in feces, which is commonly used in diet studies, contradicted both our results from estimated numbers and biomass of prey consumed, which likely represent carnivore diets more accurately (Lockie 1959, Weaver 1993). If we had reported only the percent occurrence of cricetines in the culpeo diet, for example, we would have overestimated the cricetine biomass consumed and seriously underestimated the cricetine numbers consumed (Table 1), biasing our conclusions on cricetine selection. Unfortunately, with the exception of studies based on feces of pumas (e.g., Iriarte et al. 1991, Franklin et al. 1999) and skunks (Travaini et al. 1998), and studies based on culpeo stomach contents (Novaro et al. 2000), no other attempt has been made to estimate the proportions of prey numbers and biomasses consumed by carnivores studied in the Neotropics. Feeding trials to obtain conversion equations for other Neotropical carnivores are urgently needed. In the meantime, we recommend that students of carnivore diets in the region attempt to reduce biases by estimating the numbers and biomass of prey consumed using available conversion methods for similar carnivores.

\section{ACKNOWLEDGEMENTS}

We thank the Pia and Lopez families for assistance in the field, the Centro de Ecología Aplicada de Neuquén and the Catedra de Diversidad Animal II for the use of their laboratories, H. Casañas and N. Gardenal for the use of their traps, and J. Polop for the voucher specimens. M. Bongiorno and E. Donadio helped us with the analysis of feces, S. Walker helped with statistical analyses and commented on the manuscript, the Delegación Regional Centro de Parques Nacionales and Dr. Berrotaran allowed us to work on their lands, and local workers provided their cooperation. The comments of two anonymous reviewers helped us improve the manuscript.

\section{LITERATURE CITED}

BELSKY AJ \& DM BLUMENTHAL (1997) Effects of livestock grazing on stand dynamics and soils in upland forest of the interior west. Conservation Biology 11: 315-327.

BONINO N \& JC BUSTOS (1994) Peso y dimensiones del cuerpo y órganos internos de la liebre europea en la Patagonia Argentina. Iheringia, Serie Zoología 77: 83-88.

BRUCE P, J SIMON, T OSWALD (1995) Resampling Stats: user's guide. Resampling Stats. Inc., Arlington, Virginia, USA. $128 \mathrm{pp}$.

BUCKLAND ST, DR ANDERSON, KP BURNHAM \& JL LAAKE (1993) Distance sampling: estimating abundance of biological populations. Chapman \& Hall, London, United Kingdom. xv + 446 pp.

CABIDO M, SI MOLINA, N PEREZ HARGUINDEGUY, G VALLADARES, E PUCHETA \& S GARDNER (1999) Uso de la tierra, estructura del hábitat y biodiversidad, en ecosistemas del centro de la Argentina. In: Matteucci SD, OT Solbrig, J Morello \& G Halffter (eds) Biodiversidad y uso de la tierra: conceptos y ejemplos de Latinoamerica: 421-442. Colección CEA, Universidad de Buenos Aires, Buenos Aires, Argentina.

CABRERA A (1931) On some South American canine genera. Journal of Mammalogy 12: 54- 67.

CABRERA A (1958) Catálogo de los mamíferos de América del Sur. Revista del Museo Argentino de Ciencias Naturales Bernardino Rivadavia, Zoología 4: 1308.

CABRERA A (1976) Regiones fitogeográficas argentinas. Enciclopedia argentina de agricultura, ganaderia y jardinería: 27-28. ACME, Buenos Aires, Argentina. 
CHEHEBAR C \& S MARTÍN (1989) Guía para el reconocimiento microscópico de los pelos de mamíferos de la Patagonia. Doñana, Acta Vertebrata 16: 247-291.

DIAZ S, A ACOSTA \& M CABIDO (1994) Community structure in montane grasslands of central Argentina in relation to land use. Journal of Vegetation Science 5: 483-488.

EBENSPERGER LA, JE MELLA \& JA SIMONETTI (1991) Trophic-niche relationships among Galictis cuja, Dusicyon culpaeus, and Tyto alba in central Chile. Journal of Mammalogy 72: 820-823.

ECCARD JA, RB WALTHER \& SJ MILTON (2000) How livestock grazing affects vegetation structure and small mammal distribution in the semi-arid Karoo. Journal of Arid Environments 46: 103-106.

ESTES JA (1996) Predators and ecosystem management. Wildlife Society Bulletin 24: 390-396.

FERNANDEZ GJ \& SM ROSSI (1998) Medullar type and cuticular scale patterns of hairs of rodents and small marsupials from the Monte shrubland (San Luis province, Argentina). Mastozoología Neotropical (Argentina) 5: 109-116.

FLEISCHNER TL (1994) Ecological costs of livestock grazing in western North America. Conservation Biology 8: 629-644.

FRANKLIN WL, WE JOHNSON, RJ SARNO \& JA IRIARTE (1999) Ecology of the Patagonia puma Felis concolor patagonica in southern Chile. Biological Conservation 90: 33- 40.

GESE EM (2001) Monitoring of terrestrial carnivore populations. In: Gittleman JL, SM Funk, D MacDonald \& RK Wayne (eds) Carnivore conservation: 372-396. Cambridge University Press, Cambridge, United Kingdom.

HAYWARD B, EJ HESKE \& CW PAINTER (1997) Effects of livestock grazing on small mammals at a desert cienaga. Journal of Wildlife Management 61: 123129.

HOLLING CS (1986) The resilience of terrestrial ecosystems: local surprise and global change. In: Clark WC, RE Munn (eds) Sustainable development of the biosphere: 292-320. IIASA, Cambridge University Press, Cambridge, United Kingdom.

IRIARTE JA, JE JIMÉNEZ, LC CONTRERAS \& FM JAKSIC (1989) Small-mammal availability and consumption by the fox, Dusicyon culpaeus, in central Chilean scrublands. Journal of Mammalogy 70: 641-645.

IRIARTE JA, WE JOHNSON, WL FRANKLIN (1991) Feeding ecology of the Patagonia puma in southernmost Chile. Revista Chilena de Historia Natural 64: 145-156.

JAKSIC FM, RP SCHLATTER \& JL YÁÑEZ (1980) Feeding ecology of central Chilean foxes, Dusicyon culpaeus and Dusicyon griseus. Journal of Mammalogy 61: 254-260.

JAKSIC FM, JE JIMÉNEZ, SA CASTRO \& P FEISINGER (1992) Numerical and functional response of predators to a long-term decline in mammalian prey at a semiarid Neotropical site. Oecologia 89: 90-101.

JIMÉNEZ JE, JL YÁÑEZ, EL TABILO \& FM JAKSIC (1996) Niche-complementarity of South American foxes: reanalysis and test of a hypothesis. Revista Chilena de Historia Natural 69: 113-123.
JOHNSON WE \& WL FRANKLIN (1994) Role of body size in the diets of sympatric gray and culpeo foxes. Journal of Mammalogy 75: 163-174.

JONES KB (1981) Effects of grazing on lizard abundance and diversity in western Arizona. Southwestwern Naturalist 26: 107-115.

KAZMAIER RT, EC HELLGREN, DC RUTHVEN III \& DR SYNATZSKE (2001) Effects of grazing on the demography and growth of the Texas tortoise. Conservation Biology 15: 10911101.

KNOWLTON FF (1984) Feasibility of assessing coyote abundance on small areas. Final report, Work Unit 909, Denver Wildlife Research Center, Denver, Colorado, USA. 14 pp.

LAAKE JL, ST BUCKLAND, DR ANDERSON, \& KP BURNHAM (1996) DISTANCE 2.2. Colorado Cooperative Fish and Wildlife Research Unit, Colorado State University, Fort Collins, Colorado, USA.

LARIVIÉRE S \& M PASITSCHNIAK-ARTS (1996) Vulpes vulpes. Mammalian Species 537: 1-11.

LOCKIE JD (1959) The estimation of the food of foxes. Journal of Wildlife Management 23: 224-227.

LOCKIE JD (1961) The food of the pine marten Martes martes in west Ross-shire, Scotland. Proceedings of the Zoological Society of London 136: 187-195.

LUTI R, MAB DE SOLIS, FM GALERA, NM DE FERREIRA, M BERZAL, M NORES, MA HERRERA \& JC BARRERA (1979) Vegetación. In: Vázquez J, R Miatello \& E Roqué (eds) Geografía física de la provincia de Córdoba: 297-368. Editorial Boldt, Buenos Aires, Argentina.

MARTÍN R, A RODRÍGUEZ \& M DELIBES (1995) Local feeding specialization by badgers (Meles meles) in a Mediterranean environment. Oecología 101: 45-50.

MERIGGI A \& S LOVARI (1996) A review of wolf predation in southern Europe: does the wolf prefer wild prey to livestock? Journal of Applied Ecology 33: 1561-1571.

MESERVE PL, JR GUTIÉRREZ, JA YUNGER, LC CONTRERAS \& FM JAKSIC (1996) Role of biotic interactions in a small mammal assemblage in semiarid Chile. Ecology 77: 133-148.

MEYERS K, I PARER, D WOOD \& BD COOKE (1994) The rabbit in Australia. In: Thompson HV \& CM King (eds) The European rabbit: the history and biology of a successful colonizer: 108-157. Oxford University Press, Oxford, United Kingdom.

NOVARO AJ (1997) Pseudalopex culpaeus. Mammalian Species 558: 1-8.

NOVARO AJ, MC FUNES \& RS WALKER (2000) Ecological extinction of native prey of a carnivore assemblage in Argentine Patagonia. Biological Conservation 92: 25-33.

OTIS DL, KP BURNHAM, GC WHITE \& DR ANDERSON (1978) Statistical inference from capture data on closed animal populations. Wildlife Monograph 62: $1-135$.

POLOP JJ (1989) Distribution and ecological observations of wild rodents in Pampa de Achala, Cordoba, Argentina. Studies on Neotropical Fauna and Environment 24: 53-59. 
POLOP JJ (1991) Distribución de cricétidos en las Sierras de Achala (Provincia de Córdoba, Argentina). Revista de la Universidad Nacional Río Cuarto (Argentina) 11: 115-121.

PUCHETA E, M CABIDO, S DÍAZ \& G FUNES (1998) Floristic composition, biomass, and aboveground net plant production in grazed and protected sites in a mountain grassland of central Argentina. Acta Oecologica 19: 97-105.

PYKE GH, HR PULLIAM \& EL CHARNOV (1977) Optimal foraging: a selective review of theory and tests. Quarterly Review of Biology 52: 137-154.

REDFORD KH \& JF EISENBERG (1992) Mammals of the Neotropics: the southern cone. University of Chicago Press, Chicago, Illinois, USA. ix + 430 pp.

REXSTAD E \& K BURNHAM (1991) Users' guide for interactive program CAPTURE. Abundance estimation of closed animal populations. Colorado State University, Fort Collins, Colorado, USA. 29 pp.

REYNOLDS JC \& NJ AEBISCHER (1991) Comparison and quantification of carnivore diet by fecal analysis: a critique, with recommendations, based on a study of the Fox Vulpes vulpes. Mammal Review 21: 97-122.

SACHS BN \& JCC NEALE (2002) Foraging strategy of a generalist predator toward a special prey: coyote predation on sheep. Ecological Applications 12: 299306.

Associate Editor: Fabián Jaksic

Received April 17, 2002; accepted March 19, 2003
SAUER JR \& BK WILLIAMS (1989) Generalized procedures for testing hypotheses about survival or recovery rates. Journal of Wildlife Management 53: 137-142.

SCHOENER TW (1971) Theory of feeding strategies. Annual Review of Ecology and Systematics 2: 369404.

SIMONETTI JA (1983) Effect of goats upon native rodents and European rabbits in the Chilean matorral. Revista Chilena de Historia Natural 56: 27-30.

STANLEY TR \& FL KNOPF (2002) Avian responses to late-season grazing in a shrub-willow floodplain. Conservation Biology 16: 225-231.

TRAVAINI A, M DELIBES \& O CEVALLOS (1998) Summer foods of the Andean hog-nosed skunk (Conepatus chinga) in Patagonia. Journal of Zoology (London) 246: 457-460.

WEAVER JL (1993) Refining the equation for interpreting prey occurrence in gray wolf scats. Journal of Wildlife Management 57: 534-538.

WEIR BJ (1974) The tuco-tuco and plains vizcacha. Symposium of the Zoological Society of London 34: 113-130.

ZAR JH (1996) Biostatistical analysis. Prentice Hall, Upper Saddle River, New Jersey. $x+662$ pp. 